\title{
Canine semen cryopreservation with different glycerol concentrations
}

\author{
Criopreservação do sêmen canino com diferentes \\ concentrações de glicerol
}

\author{
Alexandre Rodrigues Silva, ${ }^{\star}$ Rita de Cássia Soares Cardoso, ${ }^{*}$ Lúcia Daniel Machado da Silva ${ }^{1}$
}

\begin{abstract}
The aim of this study was to examine the effect of different glycerol concentrations on yolk-Tris extender on the cryopreservation of canine semen. The semen from five German Shepherd dogs was collected by digital manipulation, evaluated for its macro and microscopic parameters, pooled and divided into three aliquots, which were extended at $37^{\circ} \mathrm{C}$ in Tris buffer, plus $20 \%$ yolk egg. Then, the semen was submitted to an equilibrium time at $4^{\circ} \mathrm{C}$ for $1.5 \mathrm{~h}$. Finally, 4,6 or $8 \%$ of glycerol was added to the semen. Extended semen was packaged into $0.5 \mathrm{~mL}$ straws, frozen by nitrogen vapor and plunged into nitrogen liquid. After one week, it was thawed using a water bath at $37^{\circ} \mathrm{C}$ for one minute. There were no differences among glycerol concentrations concerning to the sperm motility, vigor and primary defects. However, it was shown that in the use of Tris-yolk extender plus $6 \%$ of glycerol, there was a significant lower incidence of sperm secondary and total defects. Thus, It was suggested the use of Trisyolk extender plus $6 \%$ of glycerol for canine semen cryopreservation.
\end{abstract}

Keywords: canine semen; cryopreservation; Tris, glycerol.

\begin{abstract}
Resumo
O objetivo deste estudo foi avaliar o efeito de diferentes concentrações de glicerol no diluidor Tris-gema na criopreservação do sêmen canino. O sêmen de cinco cães Pastores Alemães foi coletado por manipulação digital, avaliado quanto às suas características macro e microscópicas, homogeneizado e dividido em três alíquotas, as quais foram diluídas a $37^{\circ} \mathrm{C}$ em tampão Tris, acrescido de $20 \%$ de gema de ovo. Em seguida, procedeu-se ao período de equilíbrio a $4^{\circ} \mathrm{C}$ por $1,5 \mathrm{~h}$. Finalmente, 4,6 ou $8 \%$ de glicerol foram adicionados ao sêmen, o qual foi envasado em palhetas de $0,5 \mathrm{~mL}$ e congelado através do vapor de nitrogênio, sendo armazenado em nitrogênio líquido. Após uma semana, fez-se a descongelação em banho-maria a $37^{\circ} \mathrm{C}$ por um minuto. Não foram observadas diferenças entre as concentrações de glicerol quanto à motilidade, vigor e alterações primárias espermáticas. Entretanto, evidenciou-se que no uso do Tris-gema acrescido de $6 \%$ de glicerol, existiu uma significativa menor incidência de alterações espermáticas secundárias e totais. Desse modo, sugere-se o uso do diluidor Trisgema acrescido de $6 \%$ de glicerol para a criopreservação do sêmen canino.
\end{abstract}

Palavras-chave: sêmen canino; criopreservação; Tris, glicerol.

\section{Introduction}

Semen technology is based on its manipulation after collection. Several studies have been done to obtain the best combination among extenders, cryopreservations and thaw processes in order to improve the gestation results obtained in the canine species (Rota et al, 1999; Strom et al., 1997).

Cryoprotectors are substances whose presence is capable of improving cellular survival after the semen cryopreservation. Cryoprotective agents belong to two groups: 1) those which penetrate the cells, such as glycerol, dimethylsulfoxide (DMSO) and methanol; 2) those which stay in extra-cellular medium, such as proteins, sugars and polyvinylpirrolidone (England, 1993).
Glycerol is the most usual agent employed in different species semen cryopreservation (Rodrigues, 1997). It is a highly permeable polihidric alcohol whose cryoprotector activity was discovered by Polge et al. (1949). It allows cell dehydration by the exit of water by osmosis due to its ease in transposing the cellular membrane (Silva et al, 2000). However, its toxic effects were observed on the sperm cell (McLaughin et al., 1992) such as an osmotic shock either during exposure of the spermatozoa to the cryoprotectant or during its removal (Curry e Watson, 1994; Gao et al., 1995) and physical-chemical alterations that can cause the rupture of the plasmatic membrane or the removal of important proteins (Holt, 2000), as well as originate acrosomal damage that will reflect in a reduction of the fertility (Curry, 2000).

\footnotetext{
* Curso de Pós-Graduação em Ciências Veterinárias - Universidade Estadual do Ceará. Campus do Itaperi, 1700, CEP 60240-000, Fortaleza, Ceará, Brasil. E-mail: legio2000@yahoo.com
} 
The ideal cryoprotector concentration in the extender depends on the freezing pattern. For glycerol, this ideal concentration represents a balance between its toxic and protecting effects, because high concentrations can also affect the fertilizing capacity of the spermatozoa (England, 1993). In different extenders used to cryopreserve the semen of dogs and foxes, the final concentration of glycerol has been varied between 2 and $10 \%$ (Farstad, 1996). Moreover, in most of scientific reports, authors obtained high fertility rates after insemination with frozen semen in extenders containing between 4 and $6 \%$ glycerol (Farstad e Andersen-Berg, 1989; Wilson, 1993).

As the ideal glycerol concentration varies according to the extender, cryopreservation method and the species in study, several research centers have performed studies to establish a cryopreservation protocol for canine semen (Ravaszova et al., 1996; Rota et al., 1998). In this context, the aim of this study was to establish a protocol for canine semen cryopreserved in Tris, using three different glycerol concentrations.

\section{Material and methods}

Five stud German Shepherd dogs were selected by clinical and reproductive evaluation to be used in this study. The mean age of them was 4.5 years old and they belonged to the Military Police kennel of Ceará. Animals were fed once a day with commercial dry food, receiving water ad libitum.

Weekly, the semen of two or three dogs was collected through the digital manipulation technique by separating the semen in its three fractions (Christhiansen, 1984). The semen was placed in a water-bath at $37^{\circ} \mathrm{C}$ and transported to the laboratory. The time for this transport was about 40 minutes. At the laboratory, spermatic fractions obtained on the same day were immediately analyzed and mixed in a sperm pool, where the donor dogs were aleatory varied for each new freezing.

Spermatic fractions were analyzed for its macroscopic characteristics such as the general aspect, volume, color and viscosity of the semen, and its microscopic characteristics, such as the percentage of mobile spermatozoa (motility) and the quality of this motility (vigor) expressed on a scale from 0 to 5 (Christhiansen, 1984), which were analyzed through an optical microscope with 100 and 400x enlargement. Even those, the percentage of sperm morphologic alterations were detected by microscopic analysis $(400 \mathrm{x})$ of a sperm slide stained by a modified hematoxilin-eosin method (Concannon e Digregorio, 1996), counting 100 cells. Then, the sperm morphologic alterations were classified as primary, when related to problems originating in the sperm production, or secondary, when related to problems of sperm maturation or performed during the manipulation of the semen (Seager, 1986). Sperm concentration was determined by spectrophotometry, performing an extension of $0.1 \mathrm{~mL}$ of semen to $5 \mathrm{ml}$ of salt formol solution $(0.1 \%)$, under a length of wave of $580 \mathrm{~nm}$ (Car-
doso et al., 1997).

A Tris extender was used in this experiment. The Tris extender contained $3.028 \mathrm{~g}$ of Tris-hidroximethyl-aminometane, 1.78 $\mathrm{g}$ of monohydrated citric acid and $1.25 \mathrm{~g}$ of D-fructose, dissolved in $100 \mathrm{ml}$ of distilled water (Rodrigues, 1997; Silva et al., 2000). The osmotic pressure of this solution was 305
$\mathrm{mOsm} / \mathrm{L}$ and the $\mathrm{pH}$ 6.6. Then, $20 \%$ of the solution was substituted by egg yolk and, soon after, experimental treatments were established with the three final concentrations of glycerol to be tested: 4,6 and $8 \%$. The extender was fractioned in two equal portions. The first portion was added to the semen at $37^{\circ} \mathrm{C}$ but it did not yet contain the glycerol. The second portion contained the double of the final desired concentration of glycerol, and was added to the semen at $4^{\circ} \mathrm{C}$. The proportion of the final dilution was one part of semen to one part of extender (1:1).

The sperm pool was fractioned in three equal aliquots for the three treatments. Semen was processed by the method described by Silva et al. (2000), which consisted of performing a first dilution at $37^{\circ} \mathrm{C}$ followed by an equilibration period for $1.5 \mathrm{~h}$, when the sample reached $4^{\circ} \mathrm{C}$. The second dilution was made and the semen was packed in two $0.5 \mathrm{~mL}$ straws, which were sealed with polyvinyl alcohol. Soon, the straws were placed horizontally in a thermal box for five minutes, being to a $5 \mathrm{~cm}$ above the level of liquid nitrogen $\left(\mathrm{N}_{2}\right)$, which allowed a $70^{\circ} \mathrm{C}$ temperature provided by the $\mathrm{N}_{2}$ vapor. Then, the straws were immersed in $\mathrm{N}_{2}$ at $-196^{\circ} \mathrm{C}$. After one week, the semen was thawed in a water-bath at $37^{\circ} \mathrm{C}$ for 1 minute (Silva et al., 1998). Finally, a new microscopic evaluation of the semen was performed.

Five sperm pool were frozen in this experiment. Results were expressed as average and standard derivation. The threeglycerol concentration effect on the microscopic seminal parameters was compared by the Mann-Whitney nonparametric test. Differences among treatments were considered significant when $P<0,05$.

\section{Results}

Fresh semen of the five dogs used in this experiment had normal aspect with sperm fraction of white coloration, milk viscosity, medium volume of $2.8( \pm 1.0) \mathrm{mL}$ and concentration of $447( \pm 252.7) \times 10^{6}$ spermatozoa $/ \mathrm{mL}$. Sperm motility of 95.6 $( \pm 5.4) \%$ with vigor of $4.8( \pm 0.4)$ was observed. A total of $14.1( \pm$ $7.6) \%$ of spermatozoa with morphologic alterations was also found, $0.8( \pm 0.8) \%$ being primary and $14.6( \pm 76) \%$ secondary.

The increase in glycerol concentrations affected neither the sperm motility, nor the vigor ( $P>0.05-$ Table 1). Nevertheless, glycerol concentrations of 4 and $8 \%$ increased significantly the secondary sperm alterations $(P<0.05)$, when compared to the $6 \%$ concentration (Table 2 ).

Table 1: Sperm motility and vigor after thaw on the canine semen extended at Tris-yolk with different glycerol concentrations $(P>$
$0,05)$

\begin{tabular}{lll}
\hline Glycerol concentration (\%) & Motility (\%) & Vigor $(0-5)$ \\
\hline $4^{*}$ & $46 \pm 13,4$ & $1,6 \pm 0,8$ \\
$6^{*}$ & $43 \pm 17,9$ & $2,3 \pm 0,8$ \\
$8^{*}$ & $35 \pm 16,6$ & $2,1 \pm 0,4$ \\
\hline
\end{tabular}

${ }^{*} n=$ Five repetitions for each treatment 
Table 2: Percentage of sperm morphologic alterations after thaw on the canine semen extended at Tris-yolk with different glycerol concentrations (mean \pm SD)

\begin{tabular}{llll}
\hline Glycerol Concentration (\%) & \multicolumn{3}{c}{ Sperm morphologic alterations (\%) } \\
\cline { 2 - 4 } & Primary & Secondary & Total \\
\hline $4^{*}$ & $1,6 \pm 1,7^{\mathrm{a}}$ & $23,6 \pm 7,1^{\mathrm{b}}$ & $22,0 \pm 8,1^{\mathrm{b}}$ \\
$6^{*}$ & $0,4 \pm 0,9^{\mathrm{a}}$ & $13,2 \pm 3,1^{\mathrm{a}}$ & $12,8 \pm 3,6^{\mathrm{a}}$ \\
$8^{*}$ & $2,0 \pm 1,9^{\mathrm{a}}$ & $37,6 \pm 14,4^{\mathrm{b}}$ & $35,6 \pm 14,3^{\mathrm{b}}$ \\
\hline
\end{tabular}

a.b,c Values with different superscripts in the same column differ to each other $(P<0,05)$

${ }^{*} n=$ Five repetitions for each treatment

\section{Discussion}

The physiological seminal parameters of the dogs used in this study were considered normal for the canine species (Christhiansen, 1984). All the ejaculates were considered excellent (Dobrinsky et al, 1993; Rota et al, 1999; Silva e Verstegen, 1995).

After thawing, statistical differences were not observed for the sperm motility and vigor among the three tested treatments (Table 1). In all of these, the values of 46,43 and $35 \%$ of mobile spermatozoa were found in the treatments with 4,6 and $8 \%$ of glycerol, respectively. These values were acceptable for the use of frozen semen in artificial inseminations, because according to Concannon \& Battista (1989), at least $30 \%$ of mobile spermatozoa are needed.

In general, when semen samples are thawed, there is deterioration in the semen quality when compared with the original ejaculated. It is indicated by a marked reduction in sperm motility (England \& Ponzio, 1996; Ferguson et al., 1989). Although it is the main parameter observed to evaluate semen cryopreservation success (England, 1993), the relationship between sperm motility and fertilizing capacity of the canine spermatozoa has not yet been completely elucidated (IvanovaKicheva et al., 1997). Probably, in this study, the marked reduction of the post-thaw sperm motility was accentuated because of the transport period of the semen at $37^{\circ} \mathrm{C}$ from the kennel where the samples were collected to the laboratory. It delayed the beginning of processing, which could have decreased the spermatozoa metabolic reservations, making spermatozoa more susceptible to the damage from cooling, freezing and thawing. Thus, it is possible that beginning processing immediately after the collection of the semen favors post thaw sperm quality.

\section{References}

CARDOSO, R. C. S.; SILVA, A .R.; SILVA, L. D. M. Relação entre o espectrofotômetro e a câmara de Newbauer na determinação da concentração espermática. ENCONTRO DE INICIAÇÃO CIENTÍFICA DA UECE, 6, 1997, Fortaleza. Anais..., 1997, p. 284.

CHRISTHIANSEN, I. J. (Ed.) Reproduction in the dog and the cat. London: Ballière Tindall., 1984.

CONCANNON, P. W.; DIGREGORIO, G. B. Canine vaginal cytology. In: BURKE, T. J. (Ed.) Small Animal Reproduction and Infertility: a Clinical Approach to Diagnosis and Treatment. Fhiladelphia: Lea and Febiger, 1996. p. 66-111.
A significantly lower incidence of total and secondary sperm alterations was found in the $6 \%$ glycerol treatment when it was compared to the 4 and $8 \%$ of glycerol treatments (Table 2). Probably, for the cryopreservation method adopted in this experiment, the concentration of $6 \%$ glycerol in Tris-yolk extender would be the most appropriate, promoting a better balance among toxics and protecting effects of this cryoprotector. Besides, the mean value of $13.2( \pm 3.1) \%$ of total alterations found in the use of this treatment is acceptable for its indication to use that semen in artificial inseminations (Linde-Forsberg \& Forsberg, 1989).

In the $4 \%$ glycerol treatment, many coiled tail spermatozoa were observed after thawing. This is an indicative of a failure in its protection during temperature changes in cryopreservation and thawing. Furthermore, in the $8 \%$ glycerol treatment, several spermatozoa were observed with partial or total rupture of the tail. This discovery could have been caused during the confection of the slide or as a result of a toxic effect from the high glycerol concentration over the spermatozoa tail membrane. Gao et al. (1993) suggested that the addition and removal of cryoprotectant in molar proportions applies a substantial but transient osmotic stress to the plasma membrane of spermatozoa, depending upon the relative permeability of the cryoprotectant.

Results of this study agree with those found by Ravaszova et al. (1996), who also used Tris-yolk extender added to 4, 6 and $8 \%$ of glycerol for canine semen freezing. These authors found that concentrations of 4 and $6 \%$ would be more adapted for this purpose, because these concentrations did not differ for the sperm motility and the percentage of intact acrosomes, even if this last parameter was not measured in the present work. However, Peña et al. (1998) suggested that $8 \%$ glycerol concentration in the same extender promotes a better preservation for the sperm quality during canine semen cryopreservation. It is possible that this disparity of results is due to the use of different cryopreservation methods, because the modification of a single variable can cause many different results.

In this experiment, a sperm pool was used and the effect of glycerol on the semen of isolated dogs was not observed. Rota (1998) reported that there is a negative effect of pool for the semen quality, which is reflected on a reduction of spermatozoa with intact plasmalema. Thus, it is suggested the canine semen from different donors should not be mixed for the freezing process.

Concluding, the use of Tris-yolk extender added to $6 \%$ glycerol is suggested for canine semen cryopreservation.

CONCANNON, P. W.; BATTISTA, M. Canine semen freezing and artificial insemination. In: KIRK, R.W. (Ed.) Current Veterinary Therapy: Small Animal PracticeX. Philadelphia: WB Saunders, 1989. p. 1247-1259.

CURRY, M. R. Cryopreservation of semen from domestic livestock. Rev. Reprod., v. 5, p. 46-52, 2000.

CURRY, M. R.; WATSON, P. F. Osmotic effects on ram and human sperm membranes in relation to thawing injury. Cryobiology, v. 31, p. 39-46, 1994.

DOBRINSKY, I.; LULA, I.; BARTH, A. D.; POST, K. Effects of four different extenders and three different freezing rates on post-thaw viability of dog semen. J Reprod Fertil, v. 47, p. 291-296, 1993. 
ENGLAND, G. C. W.; PONZIO, P. Comparison of the quality of frozenthawed and cooled-rewarmed dog semen. Theriogenology, v. 46, $p$. 165-171, 1996.

ENGLAND, G. C. W. Cryopreservation of dog semen: a review. J. Reprod. Fert, v. 47, p. 243-255, 1993.

FARSTAD, W. Semen cryopreservation in dogs and foxes. Anim Reprod Sci, v. 42, p. 251-260, 1996.

FARSTAD, W.; ANDERSEN-BERG, K. Factors influencing the success rate of artificial insemination with frozen semen in the dog. J Reprod Fertil, v. 39, p. 293-298, 1989

FERGUSON, J. M.; RENTON, J. P.; FARSTAD, W.; DOUGLAS, T. A. Insemination of beagle bitches with frozen semen, J Reprod Fertil, v. 39, p. 289-292, 1989.

GAO, G. Y.; ASHWORTH, E.; WATSON, P. F.; KLEINHANS, F.W.; MAZUR P.; CRITSER, J. K. Hyperosmotic tolerance of human spermatozoa separate effects of glycerol, sodium chloride and sucrose on spermolysis. Biol. Reprod., v. 49, p. 112-123, 1993.

GAO, D. Y.; LIU, J.; LIU, C.; MCGANN, L. E.; WATSON, P. F.; KLEINHANS F.W., MAZUR, P.; CRITSER, E. S.; CRITSER, J. K. Prevention of osmotic injury to human spermatozoa during addition and removal of glycerol. Human Reprod, v. 10, p. 1109-1122, 1995.

HOLT, W. V. Fundamental aspects of sperm cryobiology: the importance of species and individual differences. Theriogenology, v. 53, p. 47-58, 2000.

IVANOVA-KICHEVA, M. G.; BOBADOV, N.; SOMLEV, B. Cryopreservation of canine semen in pellets and in 5-ml aluminum tubes using three extenders. Theriogenology, v. 48, p. 1343-1349, 1997.

LINDE-FORSBERG, C.; FORSBERG, M. Fertility in dogs in relation to semen quality and the time and site of insemination with fresh and frozen semen. J Reprod Fert, v. 39, p. 299-310, 1989.

MCLAUGHIN, E. A.; FORD, W. C. L.; HULL, M. G. R. The contribution of the toxicity of a glycerol-egg-yolk-citrate cryopresenative to the decline in human sperm motility during cryopreservation. J Reprod Fertil,
v. 95, p. 749-754, 1992.

PEÑA, A. I.; BARRIS, F.; QUINTELA, L. A.; HERRADÓN, P. G. Effect of different glycerol on frozen-thawed dog sperm longevity and acrossomal integrity. Theriogenology, v. 50, p. 163-174, 1998.

POLGE, C.; SMITH, A. U.; PARKES, A. S. Revival of spermatozoa after vitrification and dehydratation at low temperature. Nature, v. 164, p.
166,1949 .
RAVASZOVA, O.; MESAROS, P.; CINGAKOVA, V.; LUKACINOVA, M. A study of the properties of dog ejaculate during long-term storage. Folia Veterinária, v. 40, p. 95-99, 1996.

RODRIGUES B. A. Efeito do diluidor à base de albumina sérica bovina (BSA) sobre a viabilidade in vitro do sêmen canino criopreservado. 1997, 176 f. Dissertação (Mestrado) - Curso de Pós-Graduação em Ciências Veterinárias - Universidade Federal do Rio Grande do Sul 1997.

ROTA, A. Studies on preservation, capacitation and fertility of dog spermatozoa. 1998, $148 \mathrm{f}$. Tese (Doutorado) - Swedish University of Agricultural Sciences, 1998.

ROTA, A.; IGUER-OUADA, M.; VERSTEGEN, J.; LINDE-FORSBERG, C Fertility after vaginal or uterine deposition of dog semen frozen in a Tris extender with or without Equex STM Paste. Theriogenology, v. 51 p. 1045-1058, 1999.

ROTA, A.; LINDE-FORSBERG, C.; VANNOZZI, J.; ROMAGNOLI, S.; RODRIGUEZ-MARTINEZ, H. Cryosurvival of dog spermatozoa at different glycerol concentrations and freezing/thawing rates. Reproduction in Domestic Animals, v. 33, n. 5, p. 355-361, 1998.

SEAGER, S. W. J. Artificial insemination in dogs. In: BURKE, T.J. (Ed.) Small Animal Reproduction And Infertility: A Clinical Approach To Diagnosis And Treatment. Philadelphia: Lea and Febiger, p. 207-217, 1986.

SILVA, A. R.; CARDOSO, R. C. S.; SILVA, L. D. M. Efeito do processo de descongelação sobre a viabilidade do sêmen canino in vitro. $\mathrm{Ci}$. Anim., v. 8, n. 12, p. 75-80, 1998.

SILVA, A. R.; CARDOSO, R. C. S.; SILVA, L. D. M. Congelação de sêmen canino com diferentes concentrações de gema de ovo e glicerol em diluidores à base de Tris e água de coco. Ci. Rur., v. 6, p. 10211025, 2000.

SILVA, L. D. M.; VERSTEGEN, J. P. Comparisons between three different extenders for canine intrauterine insemination with frozen-thawed spermatozoa. Theriogenology, v. 44, p. 571-579, 1995.

STRÖM, B.; ROTA, A.; LINDE-FORSBERG, C. In vitro characteristics of canine spermatozoa subjected to two methods of cryopreservation. Theriogenology, v. 48, p. 247-256, 1997.

WILSON, M. S. Non-surgical intrauterine artificial insemination in bitches using frozen semen. J Reprod Fertil, v. 47, p. 307-311, 1993. 